\title{
Osteophagia by Nasutitermes guayanae (Blattodea: Isoptera: Termitidae) on human bone remains in the Andean Amazon, Caquetá, Colombia
}

\author{
Yardany RAMOS-PASTRANA ${ }^{1,2 *}$, E, Eric CÓRDOBA-SUAREZ ${ }^{1}$, Marta WOLFF² $^{2}$ \\ 1 Universidad de la Amazonia, Grupo de Investigación en Entomología - GIEUA, Laboratorio de Entomología, Florencia, Caquetá, Colombia \\ ${ }^{2}$ Universidad de Antioquia, Instituto de Biología, Grupo de Entomología - GEUA, Medellín, Colombia \\ "Corresponding author: ya.ramos@udla.edu.co; (D) https://orcid.org/0000-0002-3193-6659
}

\begin{abstract}
We present the first report of Nasutitermes guayanae feeding on human bone remains found in an urban area of the municipality of Florencia, Caquetá, Colombia, in the Colombian Amazon piedmont. The record indicates an expansion in the diet of these termites. The observation suggests that the association of $N$. guayanae with decomposing bodies may be a possible tool for the estimation of postmortem intervals.
\end{abstract}

KEYWORDS: bones, forensic entomology, Nasutiterminae, necrophagous insect

\section{Osteofagia por Nasutitermes guayanae (Blattodea, Isoptera, Termitidae) sobre restos óseos humanos en la Amazonia Andina, Caquetá, Colombia}

\section{RESUMEN}

Presentamos el primer reporte de Nasutitermes guayanae alimentándose de restos óseos humanos encontrados en un área urbana del município de Florencia, Caquetá, Colombia, en el Piedemonte Amazónico colombiano. El registro indica una expasión en la dieta de esas térmitas. La observación sugiere que la asociación de $N$. guayanae con cuerpos en descomposición puede ser una posible herramienta para la estimación de intervalos postmortem.

PALABRAS CLAVE: entomología forense, huesos, insecto necrófagos, Nasutiterminae

Termites (Blattodea: Isoptera) are a specific group of nestbuilding, hemimetabolous insects characterized by eusocial behavior that includes castes (queen, king, workers, soldiers, and winged adults). They are found in tropical and subtropical regions (Prestes et al. 2014), are linked to a diverse range of substrates, and are represented by nearly 3,000 described species of which 612 are found in the Neotropical region (Constantino 2021). Although there are 26 recorded genera of Isoptera in Colombia (Vargas-Niño et al. 2005), there exists no species compilation or catalog for the country so far. Nevertheless, recent studies have demonstrated a considerable diversity associated to vegetable crops (Abadía et al. 2013; Beltrán-Diaz and Pinzón-Florían 2018). Termites are grouped into nine families (Krishna et al. 2013). Termitidae is the most diverse with 85 genera and 436 species (Constantino 2021). Three families have been reported in Colombia: Termitidae, Kalotermitidae and Rhinotermitidae (Vargas-Niño et al. 2005). The basic diet of termites is wood, however, in addition to vegetable material, the Termitidae may also feed on fungi, lichens, hummus, termite feces, nest materials, dead termites (cannibalism), and mammal carcasses (Lima and Costa-Leonardo 2007). Thus, the Termitidae are considered ecologically relevant in the tropics for the recycling of organic matter, which facilitates nutrient cycling and improves the soil properties (Ashton et al. 2019).

Nasutitermes (Dudley, 1890) is considered the most diverse and widely distributed genus in the tropical region, with 248 described species (Constantino 2021). They feed mainly on wood and build nests with different shapes in different habitats, among which there are balloon-shaped nests on trees connected to the ground by galleries, mounds above ground level, and epigeal or subterranean nests (Pearce 1997).

Concerning necrophagy, there have been reports of the presence of Nasutitermes in vertebrate carcasses such as boas, sloths, turtles, agoutis (Thorne and Kimsey 1983), dogs (Eloi et al. 2020), and human bone remains (Derry 1911; Light 1929; Wood 1976; Wylie et al. 1987), among others (Table 1). Here we report a case of osteophagia by Nasutitermes 
Table 1. Species of termites (Blattodea: Isoptera) recorded in association with mammal carcasses. Adapted from Prestes et al. (2014).

\begin{tabular}{|c|c|c|c|c|}
\hline Species & Subfamily & Type of carcass & Local & Reference \\
\hline Nasutitermes guayanae (Holmgren) & Termitidae: Nasutiterminae & Human bones & Florencia, Caquetá, Colombia & This study \\
\hline Nasutitermes callimorphus Matheuus & Termitidae: Nasutiterminae & Canis familiaris & Brazil & Eloi et al. 2020 \\
\hline Anitermes amifer silvestri & Termitidae: Amitermitinae & Human bones & Brazil & Queiroz et al. 2017 \\
\hline Nasutitermes corniges (Motschulsky) & Termitidae & Human bones & Brazil & Queiroz et al. 2017 \\
\hline Microcerotermes indistinctus Hagen & Termitidae: Amitermitinae & Human bones & Brazil & Queiroz et al. 2017 \\
\hline Rhynchotermes nasutissimus (Silvestri) & Termitidae: Syntermitinae & Rat & Brazil & Prestes et al. 2014 \\
\hline Trinervitermes trinervoides (Sjöstedt) & Termitidae: Nasutitermitinae & $\begin{array}{c}\text { Gallus domesticus, Ovis aries, } \\
\text { bovid bones }\end{array}$ & Sterkfontein Valley, South Africa & Backwell et al. 2012 \\
\hline Unknown & Unknown & Human bones & Huaca de Luna, Peru & Huchet et al. 2011 \\
\hline Reticulitermes sp. & Rhinotermitidae & Pig carrion & Uyo, Nigéria & Ekanem and Dike 2010 \\
\hline Unknown & Termitidae & Rat carrion & Caracas, Venezuela & Velásquez 2008 \\
\hline Odontotermes sp. & Termitidae: Macrotermitinae & Grant's gazelle (also hooves) & Serengueti, Tanzania & Freymann et al. 2007 \\
\hline Unknown & Unknown & Human fossil & Laetoli, Tanzania & Kaiser 2000 \\
\hline Unknown & Unknown & $\begin{array}{c}\text { Elephants and buffalo } \\
\text { bones }\end{array}$ & Zaire, Angola & Tappen 1994 \\
\hline Mastotermes darwiniensis (Froggatt) & Termitidae: Macrotermitinae & Elephants bones & Hwange National Park, Zimbabwe & Haynes 1991 \\
\hline Pseudacanthotermes militaris (Hagen) & Mastotermitidae & Elephant bones & Hwange National Park, Zimbabwe & Haynes 1991 \\
\hline Nasutitermes carnarvonensis (Hill) & Termitidae: Nasutitermitinae & Human bones & Carnarvon Region, Australia & Wylie et al. 1987 \\
\hline Coptotermes acinaciformis (Froggatt) & Rhinotermitidae & $\begin{array}{l}\text { Recent and fossil mammal } \\
\text { bones }\end{array}$ & Laboratory experiment & Watson and Abbey 1986 \\
\hline Nautitermes nigriceps (Haldeman) & Termitidae: Nasutitermitinae & $\begin{array}{l}\text { Boa, agouti, three-toed } \\
\text { sloth, turtle }\end{array}$ & Barro Colorado, Panama & Thorne and Kimsey 1983 \\
\hline Nautitermes nigriceps (Haldeman) & Termitidae: Nasutitermitinae & $\begin{array}{l}\text { Boa, agouti, three-toed } \\
\text { sloth, turtle }\end{array}$ & Barro Colorado, Panama & Thorne and Kimsey 1983 \\
\hline Odontotermes zambesiensis (Sjöstedt) & Termitidae: Macrotermitinae & $\begin{array}{l}\text { Elephant cartilages and } \\
\text { ligaments }\end{array}$ & Tsavo, Kenia & Coe 1978 \\
\hline Unknown & Unknown & Cow jaw bones & Amboseli National Park, Kenia & Behrensmeyer 1978 \\
\hline Unknown & Unknown & Human bones & Queensland, Australia & Wood 1976 \\
\hline Coptotermes formosanus Shiraki & Rhinotermitidae & Human bones & China & Light 1929 \\
\hline Unknown & Unknown & Human bones & Ancient Nubia, Egypt & Derry 1911 \\
\hline
\end{tabular}

guayanae (Holmgren, 1910) on human bone remains in Colombia, which suggests a possible use for the determination of the postmortem interval in future cases as a new tool in forensic sciences.

On February 11, 2018, at 11:00 a.m., a skeletonized human body was found, approximately one kilometer from the urban center of Florencia, Department of Caquetá, Colombia $\left(01^{\circ} 38^{\prime} 31.4^{\prime \prime N}\right.$; $\left.075^{\circ} 36^{\prime} 44.1^{\prime \prime} \mathrm{W}\right)$ (Figure 1), in the Andean piedmont between the Eastern Cordillera and the Amazon lowlands. The area is located at $310 \mathrm{~m}$ amsl with an average temperature of $25^{\circ} \mathrm{C}, 80 \%$ relative humidity, and an average annual precipitation of $3,840 \mathrm{~mm}$ (IGAC 2010). The corpse was found in an area with abundant arboreal vegetation mainly composed of Zygia longifolia (Humb. and Bonpl. ex Willd.) Britton \& Rose, 1928 at $300 \mathrm{~m}$ from the main road.

During the technical inspection of the corpse and the scene by police accompanied by authors YRP and ECS, it was noticed that the bone remains had a major termite infestation. The termites were collected, fixated in $96 \%$ ethanol, and taken to the Entomology laboratory of the Universidad de la Amazonía (Caquetá, Colombia), where they were identified with the species keys proposed by Constantino (2002; 2012) and Malpica et al. (2010), and by comparing them with the redescription proposed by Ensaf $e t$ al. (2003). The identification was confirmed by a specialist (see Acknowledgments). The specimens were examined under an Olympus stereomicroscope and a 2x auxiliary lens. Photographs were taken with a Leica digital camera DFC450 coupled to a stereomicroscope Leica M205A. This system was connected to a computer with Leica Application Suite software, with an automatic mounting module (synchronization software) (http://www.syncroscopy.com/ syncroscopy/). The map of the collection site was plotted using the Quantum GIS 2.16 software (Quantum GIS Development Team 2016). All speciemns were deposited in the Colección del Laboratorio de Entomología of Universidad de la Amazonia - LEUA. 

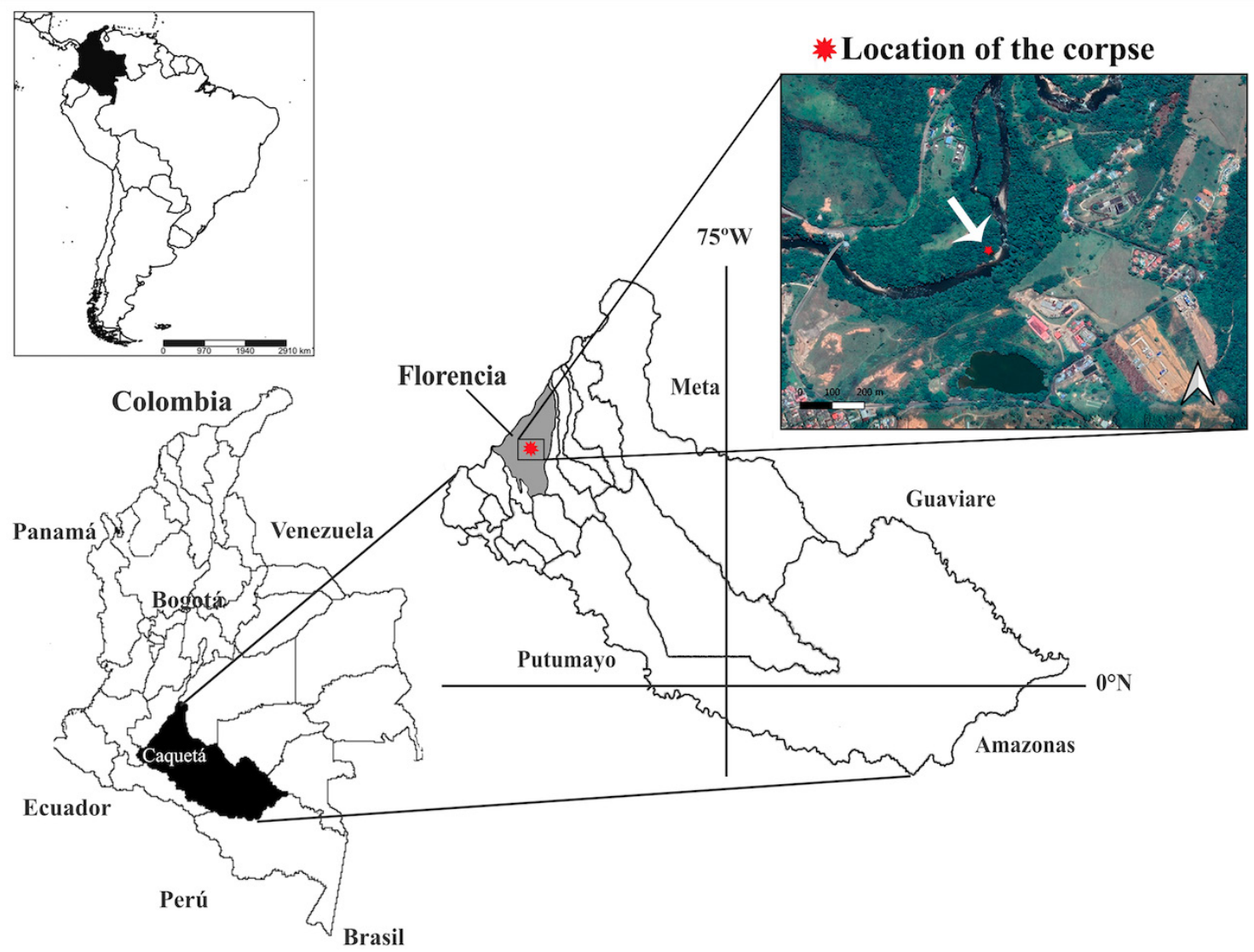

the corpse

Figure 1. Geographical location of the human bone remains infested by Nasutitermes guayanae in Florencia, Caquetá, Colombia. This figure is in color in the electronic version.

In total, $81 N$. guayanae specimens were collected, 16 soldiers (protecting the foraging area) (Figure 2a) and 65 workers (collecting the food) (Figure 2b), mainly on bone pieces such as the phalanges (Figure 3a) and the calcaneus (Figure 3b), where the bone degradation by the termites was noticeable.

Nasutitermes guayanae is distributed in Brazil, Colombia, Costa Rica, Ecuador, French Guiana, Panama, Peru, Suriname, Trinidad and Tobago, and Venezuela (Constantino 2021). The species is characterized by having 14-segment antennas, the second antenomer as long as the fourth, third antenomer shorter than the others; a conical nasus lighter colored than the head with 3-4 setae on the top and 4 setae at the base; 3-5 long and short setae in the vertex and posterior area of the head; and pronotum with 2-3 setae at the posterior margin (Malpica et al. 2010).

Regarding its biology, $N$. guayanae has occasionally been observed feeding on new and dry leaves in forests of the Brazilian Amazon (Gomes 1991), on wood (Constantino 1992), in orange plantations in the Colombian Caribbean coast (Abadía et al. 2013), and in a riparian forest in Venezuela (Malpica et al. 2010). We present the first report of $N$. guayanae feeding on human bone remains. The termites
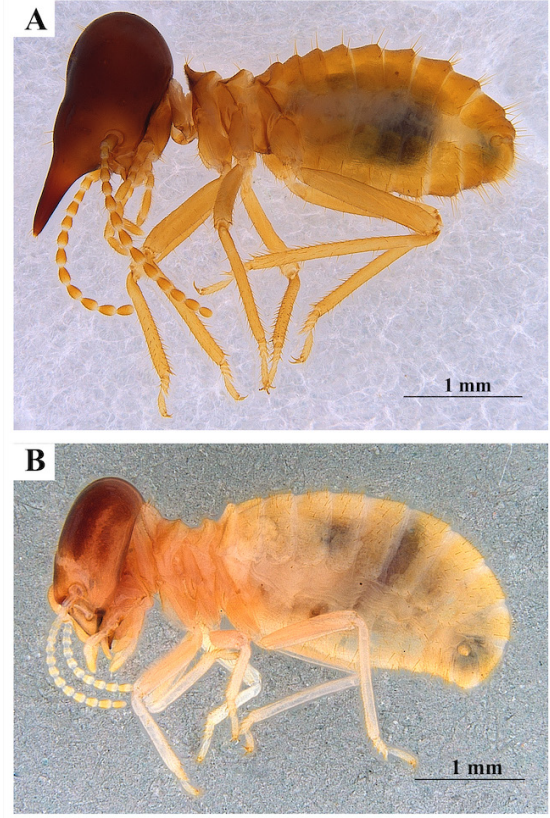

Figure 2. Adults of Nasutitermes guayanae. A - left lateral view of soldier [LEUA1149 (batch)]; B - left lateral view of worker [LEUA-1150 (batch)]. Scale bar $=1$ $\mathrm{mm}$. This figure is in color in the electronic version. 

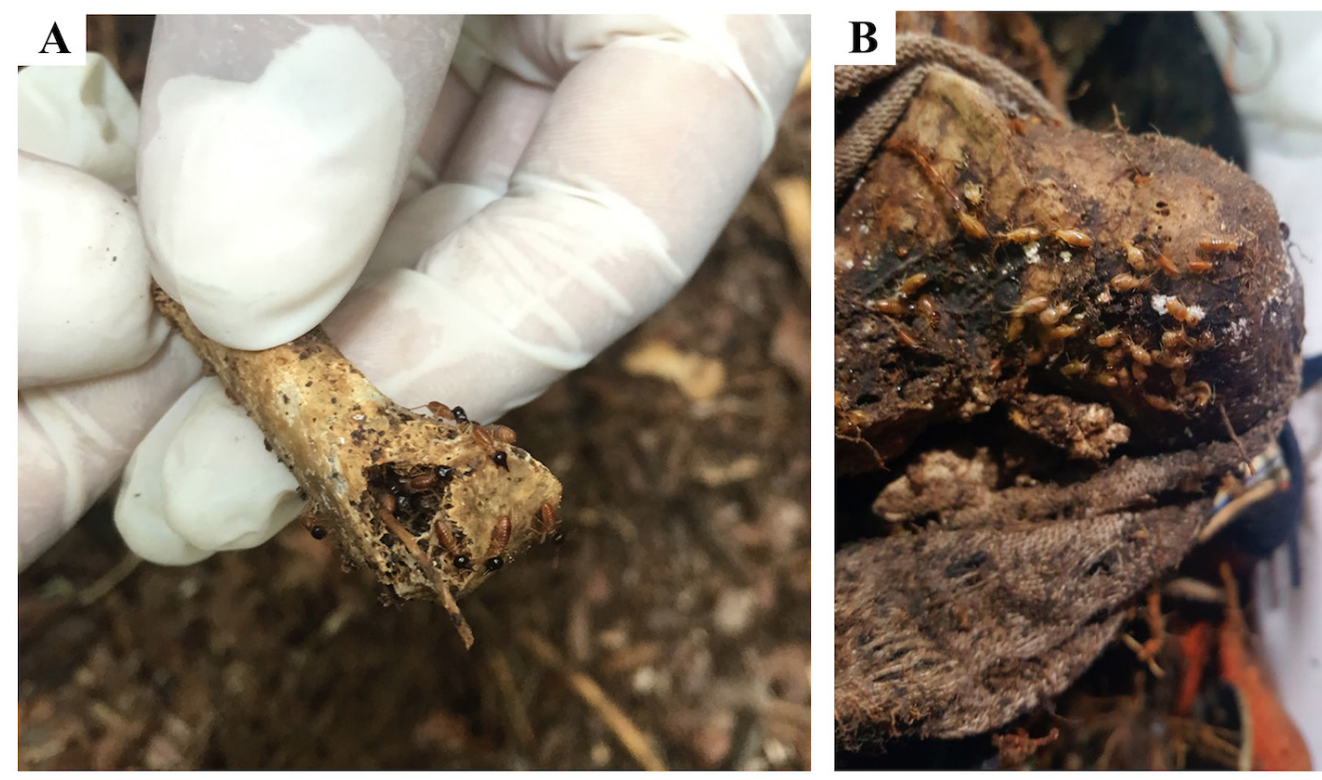

Figure 3. Bone pieces infested by Nasutitermes guayanae. A - phalanx; B - calcaneus. This figure is in color in the electronic version.

caused visible impact and damage on the bone pieces, which is consistent with the observations of Backwell et al. (2012), who claim insects, including termites, degrade bone structures to acquire the nutrients inside of them. Queiroz et al. (2017) also reported that termites can destroy bone preservation at any stage and that osteophagia can be noticed by the marks made by the termites, which are small holes and tunnels in the bone pieces.

With our observation, $N$. guayanae enters the list of termites that feed on bone remains of mammals and that are potentially relevant for forensic entomology. The association of insects with decomposing bodies is often the most accurate or the only method to determine the time elapsed after 72 hours since death (Anderson and VanLaerhoven 1996). Different decomposition states are attractive for diverse insect species, allowing the determination of a postmortem interval by determining the connection between the timing of decomposition, the identity of colonizing termites and the level of bone degradation. As the necrophagic habits of more insect species of the regional fauna become known, the local applicability of forensic entomology to establish postmortem intervals increases. Further studies should clarify the usefulness of $N$. guayanae for Neotropical forensic entomology.

\section{ACKNOWLEDGMENTS}

To Universidad de la Amazonia, the Attorney General's Office of Colombia for authorizing the publication of this case, Dr. Ervin Humpery Duran Bautista and Dr. Agno Nonato Serrão Acioli for the confirmation of the species identification, and the reviewers and the editors for their valuable contributions to this work during the review process.

\section{REFERENCES}

Abadía, J.C.; Arcila, A.M.; Chacón, P. 2013. Incidencia y distribución de termitas (Isoptera) en cultivos de cítricos de la costa Caribe de Colombia. Revista Colombiana de Entomología, 39: 1-8.

Anderson, G.S.; VanLaerhoven, S. 1996. Initial studies on insect succession on carrion in Southwestern British, Columbia. Journal of Forensic Science, 41: 617-625.

Ashton, L.A.; Griffiths, H.M.; Parr, C.L.; Evans, T.A.; Didhan, R.K.; Hasan, F.; The, Y.A.; Tin, H.S.; Vairappan, C.S.; Eggleton, P. 2019. Termites mitigate the effects of drought in tropical rainforest. Tropical Ecology, 363: 174-177.

Backwell, L.R.; Parkinson, A.H.; Roberts, E.M.; d'Errico, F.; Huchet, J.B. 2012. Criteria for identifying bone modification by termites in the fossil record. Palaeogeography, Palaeoclimatology, Palaeoecology, 338: 72-87.

Behrensmeyer, A.K. 1978. Taphonomic and ecologic informations from bone weathering. Paleobiology, 4/2: 150-162.

Beltrán-Díaz, M.A.; Pinzón-Florián, O.P. 2018. Termitofauna (Isoptera: Termitidae, Rhinotermitidae) en plantaciones de Pinus caribaeu en sabanas de la Orinoquia Colombia. Revista Colombiana de Entomología, 44: 61-71.

Britton, N.; Rose, J.N. 1930. Caesalpiniaceae. North American Flora, 23: 201-268.

Coe, M. 1978. The decomposition of elephant carcasses in the Tsavo (East) National Park, Kenya. Journal of Arid Environments, 1: 71-86.

Constantino, R. 1992. Abundance and diversity of termites (Insecta: Isoptera) in two sites of primary rain forest in Brazilian Amazonia. Biotropica, 24: 420-430. doi.org/10.11646/zootaxa.67.1.1

Constantino, R. 2002. An illustrated key to Neotropical termite genera (Insecta: Isoptera) based primarily on soldiers. Zootaxa, 67: 1-40. doi.org/10.11646/zootaxa.67.1.1 
Constantino, R. 2012. Isoptera Brullé, 1832. In: Rafael, J.A.; Melo, G.A.R.; Carvalho, C.J.B,; Casari, S.A.; Costantino, R. (Ed.). Insetos do Brasil Diversidade e Taxonomia. Holos Editora, Ribeirão Preto, p.311-321.

Constantino, R. 2021. Online Termite Database (www.termitologia. net/termite-database). Accessed on 18 Feb 2021.

Derry, D.E. 1911. Damage done to skulls and bones by termites. Nature, 86: 245-246.

Dudley, P.H. 1980. The termites of the Isthmus of Panama. Journal of the New York Microscopical Society, 6: 102-118.

Ekanem, M.S.; Dike, M.C. 2010. Arthropod succession on pig carcasses in Southeastern Nigeria. Papéis Avulsos de Zoologia, 50: $562-570$.

Eloi, I.; de Oliveira, M.H.; Bezerra-Gusmao, M.A. 2020. Carcass consumption by Nasutitermes callimorphus (Blattodea: Isoptera) in highland forests from Brazil. Journal of Threatened Taxa, 12: 16187-16189.

Ensaf, A.; Betsch, J.; Garrouste, R.; Nel, A. 2003. New data on Nasutitermes from French Guiana (Isoptera: Termitidae: Nasutitermitinae). Annales de la Société Entomolgique de France, 39: 239-245.

Freymann, B.P.; Viser, S.N.; Mayemba, E.P.; Olff, H. 2007. Termites of the genus Odontotermes are optionally keratophagous. Ecotropica, 13: 143-147.

Gomes, A.B. 1991. Térmites (Insecta: Isoptera) Consumidores de liteira na Ilha de Maracá, Roraima. Acta Amazonica, 21: 15-23.

Haynes, G. 1991. Mammoths, mastodonts and elephants. Biology, behavior and the fossil record. Cambridge University Press, Cambridge, 413p.

Holmgren, N. 1910. Versuch einer Monographie der americanische Eutermes Arten. Jahrbuch der Hamburgischen Wissenschaftlichen Anstalten, 27: 171-325.

Huchet, J.B.; Deverly, D.; Gutierrez, B.; Chauchat, C. 2011. Taphonomic evidence of a human skeleton gnawed by termites in a Moche-Civilisation grave at Huaca de la Luna, Peru. International Journal of Osteoarchaeology, 21: 92-102.

IGAC. 2010. Caquetá: Características Geográficas. Instituto Geográfico Agustin Codazzi. Bogotá, 376p.

Kaiser, T.M. 2000. Proposed fossil insect modification to fossil mammalian bone from Plio- Pleistocene hominid-bearing deposits of Laetoli (Northern Tanzania). Entomological Society of America, 93: 693-700.

Krishna, K.; Grimaldi, D.; Krishna, V.; Angel, M.S. 2013. Treatise on the Isoptera of the World. Bulletin of the American Museum of Natural History, no. 377, 2704p.
Light, S.F. 1929. Present status of our knowledge of the termites of China. Lingnan Science Journal, 7: 581-600.

Lima, J.T.; Costa-Leonardo, A.M. 2007. Recursos alimentares explorados pelos cupins (Insecta: Isoptera). Biota Neotropica, 7: $243-250$

Malpica, F.H.; Andara, C.; Varela, C.W. 2010. Especies de Nasutitermes (Isoptera: Termitidae) en la Cumaca, Municipio San Diego, Estado Carabobo, Venezuela. Faraute Ciencias y Tecnología, 5: 44-55.

Pearce, M.J. 1997. Termites: Biology and Pest Management. CAB International, Wallingford, 172p.

Prestes, C.A. Tepedino, K.P.; Kosmann, C.; Pujol-Luz, J.R. 2014. First record of Rhynchotermes nasutissimus (Silvestri) (Isoptera: Syntermitinae) associated with rat carrion in Brasília, Brazil. EntomoBrasilis, 7: 58-61.

Quantum GIS Development Team. 2016. Quantum GIS (Geographic Information System). Open Source Geospatial Foundation Project. (www.qgis.org/es/site/). Accessed on 05 Mar 2021.

Queiroz, R.A.; Soriano, E.P.; Carvalho, M.V.D.; Caldas-Junior, A.F.; Souza, E.H.A.; Coelho-Junior, L.G.T.M.; Campello, R.I.C.; Almeida, A.C.; Farias, R.C.A.P.; Vasconcellos, A. 2017. First forensic records of termite activity on non-fossilized human bones in Brazil. Brazilian Journal of Biology, 77: 127-131.

Tappen, M. 1994. Bone weathering in the tropical rain forest. Journal of Archaeological Science, 21: 667-673.

Thorne, B.L.; Kimsey, R.B. 1983. Attraction of Neotropical Nasutitermes termites to carrion. Biotropica, 15: 295-296.

Vargas-Niño, A.P.; Sánchez-Muñoz, O.D.; Serna-Cardona, F.J. 2005. Lista de los géneros de Termitidae (Insecta: Isoptera) de Colombia. Biota Colombiana, 6: 181-190.

Velásquez, Y. 2008. A checklist of arthropods associated with rat carrion in a montane locality of northern Venezuela. Forensic Science International, 174: 67-69.

Watson, J.A.L.; Abbey, H.M. 1986. The effects of termites (Isoptera) on bone: some archeological implications. Sociobiology, 11: 245-254.

Wood, W.B. 1976. The skeletal material from the Brooloo Range and Rocky Hole Creek burial sites. Archaeology and Physical Anthropology in Oceania, 11: 175-185.

Wylie, F.R.; Walsh, G.L.; Yule, R.A. 1987. Insect damage to aboriginal relics at burial and rock-art sites near Carnarvon in Central Queensland. Journal of the Australian Entomological Society, 26: 335-345.

RECEIVED: $24 / 03 / 2021$

ACCEPTED: $13 / 10 / 2021$

ASSOCIATE EDITOR: Pitágoras C. Bispo 